\title{
The Impact Assessment of the VAT reduction in Tourism Sector
}

\author{
Griselda Cela, PhD candidate in Finance \\ Part-time Lecturer, Departament of Finance, \\ Faculty of Economy, University of Tirana, Albania \\ Branch Manager,Credins Bank sh.a, Tirana, Albania
}

Doi:10.19044/esj.2018.v14n25p243 URL:http://dx.doi.org/10.19044/esj.2018.v14n25p243

\begin{abstract}
As a part of measures to support tourism sector as one of the government's strategic priorities, the Albanian government reduced the tourism value added tax (VAT).

The main purpose of this article is to analyze the effects of reducing the VAT for Tourism from $20 \%$ to $6 \%$. In order to evaluate the impact and benefit of the introduction of the VAT rate reduction in an informed manner and determine whether the objectives of the initiative have been met, the following questions are considered:

- Did the reduction in the VAT rate result in lower consumer prices in the impacted categories?

- Has there been an increase in tourist numbers as a result of the VAT rate reduction and what has been the impact on revenue?

- Has there been an increase in demand / activity in the tourism industry as a result of the VAT rate reduction?

- Has there been an increase in employment in the tourism industry as a result of the VAT rate reduction?

The assessment framework enables an indicative assessment of the VAT rate cut's impact through consideration of the key questions referred to previously. The term "indicative assessment" is used owing to the data challenges around aligning various data sets, data lags and the limited time since the cut came into effect. Clearly the question of whether a specific input or policy measure, such as the VAT decrease, has contributed strongly to, or in effect led to, an increase in tourism activity or employment within tourism sector.
\end{abstract}

Keywords: VAT; tourism; employment; revenues; impact 


\section{Literature Review}

There have been many studies on Tourisem Sector in Albania and his impact in Albanian Economy using different methods and approach. However, there aren't any studies that have been concentrated on the Impact Assessment of the VAT reductions in the Tourism Sector. The use of statistical descriptive method which supports the analysis of the effects of the VAT reduction in quantitative way. All the effects of VAT reduction are analyzed below, with a section for every effects . The effect of VAT reduction are in attracting FDI, contribution of Tourisem to the GDP of Albania, Net Incomes, Informality, Employment, Impact on prices.

\section{Data and Research Methodology}

This paper make use of the statistical approach which assists the analysis of the impact assessment of the Vat reduction in Tourisem Sector in Albania economy in a quantitative manner. Data has been obtained through secondary source for writing this paper. Majority of the information has been collected from the Ministry of Finance of Albania, General Tax Directorate (GTD), consultation with NBF members working on tourism sector and some recent information from ACER staff expertise. The data used in analyzing every effect of Vat reduction were collected :For the effect of FDI the data were collected from 2016-2018. For the effect of Contribution of the Tourism to the GDP of Albania the data were collected from 2014-2017. For the effect of the Net Incomes the Data were collected from 2014-2017. For the effect of Informality the data were collected from 2015-2017. For the effect of Informality the data were collected from 2015-2016. For the effect of Employment the data were collected from 2016-2017.For the effect on prices the data were collected in 2017.

\section{Rationale}

Tax and customs revenues are levied from all types of taxes that are implemented by the central government. In the latter are included 6 main types of categories: Value Added Tax (VAT), Profit Tax, Excise Tax, Personal Income Tax, Customs Duties, National Taxes and others. According to the figures published by the Ministry of Finance on Fiscal Indicators it is claimed that over the years, VAT has been the largest source of revenue followed by social insurance contributions ${ }^{1}$.

In the Albanian Tourism Association (ATA) ${ }^{2}$, it is stated that according to the Bank of Albania from the tourism in 2013 the VAT collection has been ALL 210 million ( EU 1.5 million). According to the General Tax Directorate

1 Ministry of Finance: Fiscal indicators regarding consolidated budget of 2017 http://www.financa.gov.al/al/thesari/treguesit-fiskal-sipas-buxhetit-te-konsoliduar

${ }^{2}$ Official letter sent to the International Monetary Fund (IMF) in November 2014 
(GTD) this amount is collected from the turnover of 1182 companies which operate in tourism sector, respectively in activities such as: agencies, hotels, restaurants, camping and tourist villages.

For years, Albania was the only country in the region, where tourism is taxed at the standard rate of 20 percent, while all other countries apply a tax rate significantly lower (Macedonia 5\%; Montenegro 7\%; Kosovo $8 \%$ and Serbia 10\%). This discrepancy could potentially cause local hotel owners to not offer competitive pricing for similar services in the region. This fact is confirmed by the World Economic Forum, which ranks our country 98th out of 136 countries, part of the Index of Competitiveness in Tourism ${ }^{3}$.

Proponents of VAT reduction argue that tourism VAT of 20 percent represents the biggest share of the fiscal burden compared to other types of taxes causing a direct impact into the prices in the sector. This fact is supported even by the ATA study. A reduction of the VAT on this sector would allow hotels, restaurants, pubs and visitor attractions to cut prices, boosting sales and employment in this sector, which in turn would encourage growth in the wider economy. According to the drafters, this law has a negative impact on the state budget revenues, in the "VAT Revenue". From the calculations, taking into account the VAT collected by the tourism sector for 2016, the negative effect on the budget will be about ALL 1.1 billion, while in 2017 ALL 1.4 billion.

Based on these facts, The Council of Ministers on 5 April 2017 issued a Draft $\mathrm{Law}^{4}$ which proposes a reduction of the VAT rate from $20 \%$ to $6 \%$ for hotels and other tourism accommodation facilities. Based on the Draft Law, the reduced rate of VAT applies to the supply of accommodation services in all accommodation facilities, as determined by the applicable legislation for the tourism sector. These facilities include:

- Hotels

- Motels

- Guest houses

- Hostels

- Camp sites

- Tourist Resorts

- Curative centers

- Bed and breakfast lodgings

At a news conference, the heads of business associations operating in the market have unanimously welcomed this initiative as very important for development of this sector. According to them, VAT reduction to the rate of 6

3 Word Economic Forum Travel and Tourisem competitiveness Index : http://reports.weforum.org/travel-and-tourism-competitiveness-report-2017/countryprofiles/\#economy=ALB

${ }^{4}$ Draft Law "On an amendment of the Law No. 92/2014 "On value added tax", as amended", published on 5 April 2017 at www.parlament.al 
percent will generate more tax revenues boost investments in this sector as well as improve the service to consumer increase employment and cut prices.

For the report we have taken information from ACER staff expertise, consultation with NBF members working on tourism sector and some recent unpublished data provided by the General Tax Directorate (GTD) for main economic aspects that were influenced by the tourism VAT and provides both graphical and textual summaries of data and addresses trends.

\section{The Economic Context}

\subsection{Encouraging investment in tourism}

In the framework of supporting and encouraging investment in tourism, the government in 2017 has undertaken a number of legislative initiatives, with the aim of creating and providing fiscal incentives, mainly in hotel market segment. Specifically, the initiatives taken regarding some tax exemption such as: profit tax exemption for a 10 -year period ${ }^{5}$, infrastructure impact tax and building tax for 4-5 stars Hotels and Resorts, which benefit a special status until December $2024^{6}$, as well as the reduction of VAT to $6 \%$ aims to make Albania more attractive for investments and to position it at the same level of competitiveness with other countries in the region in attracting FDIs ${ }^{7}$.

In the context of promoting and attracting public, private, domestic and foreign investment in the sectors of the economy, identified as strategic sectors that represent high development potential, such as tourism exists Law 55/2015 "On strategic investments in The Republic of Albania". This law determines administrative, mitigation or acceleration procedures and regulations for investors/projects benefiting from the status "Investor/Strategic Investor, Assistance Procedure/Special Procedure", according to the respective definitions. The Law on Strategic Investments in based on providing assistance to investors, as a substitute for different incentives, which are widely practiced by the neighboring countries for attracting foreign investments. Under these conditions, Albania's neighbors hold a higher position for attracting potential investors.

Also Law 93/2015 "On Tourism", amended, provides the facilities and support that benefits investments in priority areas for tourism development such as: making available state real estate (through a symbolic 1 euro contract ${ }^{8}$ ) for a period up to in 99 years. The new law encourages big investors which seek to implement touristic resorts by giving in use state owned land through

informalitetit/

${ }^{6}$ Ligj nr. 107/2017, datë 30/11/2017. Botuar në Fletoren Zyrtare nr. 222, datë 19.12.2017),

${ }^{7}$ Ligj nr. 71/2017, datë 27/04/2017. Botuar në Fletoren Zyrtare nr. 113, datë 22 maj 2017.

${ }^{8}$ AIDA, Albanian Investment Development Agency http://aida.gov.al/images/publikime/docs/Albania_Calls_01_low.pdf 
the "Albania 1 Euro scheme". Every real estate owned by the state or the local authority becomes a property under the administration of the Ministry of Tourism within two months after the area has been declared as "a priority area for the development of tourism". In the previous five years, business investment levels remained low. Therefore the promotional policies to commence operations for just 1 euro are clearly insufficient by themselves to attract investors. Similarly, efforts to develop special economic zones and enable larger infrastructure investments proposals have missed targets. This again shows that there is no single measure of the business enabling environment that will change the economic landscape in the country, but these measure need to be considered and implemented as a package and in parallel.

The failure to fully achieve the aforementioned strategic objectives is closely related to the lack of sufficient progress with other areas related to the business climate, especially with the functioning of justice and rule of law. The latter remain possibly the most critical factor for the future of Albania. These issues are also considered problematic in many other reports that measure Albanian and other countries reforms progress. According to the Global Competitiveness Report, the level of Albanian economy competitiveness, has been decreasing - a trend that was finally halted in 2016. The main problem that businesses encounter in Albania is the high level of corruption ${ }^{9}$. The latest figures of the Corruption Perception Index of Transparency International ranks Albania 83rd out of 176, and as one of the most corrupt countries in Europe ${ }^{10}$.

\subsection{Contribution of Tourism to GDP}

The World Travel \& Tourism Council (WTTC) analysis gives clearer picture of the contribution the travel and tourism industry have on Albanian economy with regard to GDP. The direct contribution of Travel and Tourism to GDP in 2017 was ALL134.1 bn (8.5\% of GDP). This is forecast to rise by $3.9 \%$ to ALL139.3bn in 2018. This primarily reflects the economic activity generated by industries such as hotels, travel agents, airlines and other passenger transportation services (excluding commuter services). But it also includes, for example, the activities of the restaurant and leisure industries directly supported by tourists. The total contribution of Travel \& Tourism to GDP (including wider effects from investment, the supply chain and induced

\footnotetext{
${ }^{9}$ World Economic Forum: Global Competitiveness Report 2016-2017, Albania, Most problematic factors for doing business, http://reports.weforum.org/global-competitivenessindex/country-profiles/\#economy=ALB

10 Corruption Perception Index of Transparency International: https://www.transparency.org/country/ALB
} 
income impacts) was ALL414.2bn in 2017 (26.2\% of GDP) and is expected to grow by $4.4 \%$ to ALL432.3bn (26.3\% of GDP) in $2018^{11}$.

Table 1: Direct contribution of Travel and Tourism to GDP

(in billions of $A L L$ )

\begin{tabular}{|l|c|c|c|c|}
\hline & 2014 & 2015 & 2016 & 2017 \\
\hline $\begin{array}{l}\text { Contribution to } \\
\text { GDP }\end{array}$ & 82.7 & 87.6 & 127.7 & 134.1 \\
\hline $\begin{array}{l}\text { Total } \\
\text { contribution of } \\
\text { tourism to GDP }\end{array}$ & $5.9 \%$ & $6.0 \%$ & $8.4 \%$ & $8.5 \%$ \\
\hline
\end{tabular}

Source: WTTC

\subsection{Net Incomes}

Albania has collected 1.3 billion Euros in revenues from foreign citizens' travels for the period of January-September 2017, which is 13\% higher compared to the same period of 2016, reaching the highest level of revenues ever collected. But nearly 1 billion Euros are also spent by the Albanians traveling abroad the borders, thus setting the net profit in the level of 337 million Euros. Although not in the wanted level, this is a record positive balance in the history of these years. These are the data of the Bank of Albania for January-September (2017) period where the highest flux was recorded during the summer season.

During June-August, 2017 period, taxpayers carrying out "accommodation services" recorded a significant increase in turnover, compared to the same periods of 2015 and 2016. As seen from the above table, the turnover realized in June-August period is $60 \%$ higher compared to the same period in 2015 and 39\% higher than the same period in $2016^{12}$.

Table 2: Turnover realized by the accomodation units

\begin{tabular}{|c|c|}
\hline Turnover & ALL \\
\hline Total turnover in 2015 & $11,756,264,629$ \\
\hline Total turnover in 2016 & $13,528,085,004$ \\
\hline Total turnover in 2017 & $18,750,676,071$ \\
\hline
\end{tabular}

The annual growth of revenues was influenced by the $3 \%$ increase in the number of foreign visitors (non-residents) and the increase by $16 \%$ of the average expenditure of this group. According to INSTAT, the number of foreign nationals who entered the territory of Albania for January-September (2017) was about 4.2 million, an increase of $5.7 \%$ over the same period of the previous year.

\footnotetext{
${ }^{11}$ Word Travel and Tourisem Council:https://www.wttc.org/-/media/files/reports/economicimpact-research/countries-2018/albania2018.pdf

12 Generale Directorate of Tax of Albania, Data provided by the GDT: https://www.tatime.gov.al
} 
Table 3: Number of foreign visitors from 2014 to 2017

\begin{tabular}{|l|c|c|c|c|}
\hline \multicolumn{1}{|c|}{ Period } & \multicolumn{3}{|c|}{ Incoming visitors } \\
\hline 1-st Quarter & $\mathbf{2 0 1 4}$ & $\mathbf{2 0 1 5}$ & $\mathbf{2 0 1 6}$ & $\mathbf{2 0 1 7}$ \\
\hline II-nd Quarter & 463.649 & 462.823 & 561.948 & 601,940 \\
\hline III-rd Quarter & 760.925 & 929.044 & 1.038 .747 & $1,157,354$ \\
\hline IV-th Quarter & 1.696 .845 & 1.930 .424 & 2.395 .917 & $2,465,389$ \\
\hline Total & 556.346 & 622.801 & 704,831 & 893.017 \\
\hline
\end{tabular}

Source: INSTAT

Even though there is lack of data regarding companies exercising their activity in the tourism sector, thus it is impossible to separate them from other tourism-related services. Despite the above turnover analysis there are only anecdotal data confirming the improved financial situation of the tourism operators compared to the last year as well as fast growth in turnover of tourism sector compared to other sectors. This leads to the conclusion that net income of these operators has increased compared to the last year.

\subsection{Informality}

According to Mr. Ahmetaj, Minister of Finance and Economy and other business organization and chambers representatives, the VAT cutting in this sector of will lead to formalization of the latter ${ }^{13}$. The Prime Minister also explained that the VAT cut from the standard $20 \%$ to $6 \%$ for the hospitality sector will encourage its formalization ${ }^{14}$. As shown in the table below, the turnover realized during June, July and August has increased significantly from year to year. Thus, for the respective periods of 2017, there has been a $14 \%$ increase in turnover compared to the same periods of 2016. This has, inter alia, been due to self-declaration by taxpayers of the tourism sector during this period $^{15}$.

${ }^{13}$ Scan tv, Economic tv: https://www.scan-tv.com/tourism-operators-hail-vat-reduction-from20-to-6/

${ }^{14}$ Declaration from Prime office: https://kryeministria.al/en/newsroom/news/tourist-albania-and-its-endless-possibilities-forexploration\&page $=21$

15 Generale Directorate of Tax of Albania: Data provided by the GDT. https://www.tatime.gov.al . 
Table 4: The turnover declared by 4,499 taxpayers $^{16}$ of the tourism plan registered for

\begin{tabular}{|c|c|c|c|c|c|c|c|}
\hline \multicolumn{8}{|c|}{ VAT } \\
\hline Period & 2015 & 2016 & $\begin{array}{c}\text { Dif } \\
2016 / 2015\end{array}$ & $\begin{array}{c}\text { Dif } \\
\% \\
16 / 15\end{array}$ & 2017 & $\begin{array}{c}\text { Dif } \\
2017 / 2016\end{array}$ & $\begin{array}{c}\text { Dif } \\
\% \\
17 / 16\end{array}$ \\
\hline June & $\begin{array}{l}6,816,2 \\
68,114 \\
\end{array}$ & $\begin{array}{c}8,971,65 \\
2,198\end{array}$ & $\begin{array}{c}2,155,384,0 \\
84\end{array}$ & $32 \%$ & $\begin{array}{c}9,957,11 \\
3,611\end{array}$ & $\begin{array}{c}985,461,41 \\
3\end{array}$ & $11 \%$ \\
\hline July & $\begin{array}{l}8,039,2 \\
68,833\end{array}$ & $\begin{array}{c}10,494,3 \\
63,360\end{array}$ & $\begin{array}{c}2,455,094,5 \\
27\end{array}$ & $31 \%$ & $\begin{array}{c}12,734,1 \\
02,964\end{array}$ & $\begin{array}{c}2,239,739,6 \\
04\end{array}$ & $21 \%$ \\
\hline August & $\begin{array}{l}9,056,5 \\
39,178\end{array}$ & $\begin{array}{c}12,638,3 \\
37,290\end{array}$ & $\begin{array}{c}3,581,798,1 \\
12\end{array}$ & $40 \%$ & $\begin{array}{c}14,027,7 \\
94,092\end{array}$ & $\begin{array}{c}1,389,456,8 \\
02\end{array}$ & $11 \%$ \\
\hline
\end{tabular}

According to the data shown in the table below, the VAT paid by the taxpayers taken into consideration during June, July and August has increased significantly in 2016 compared to 2015 and a more modest increase in 2017 compared to 2016, this also for the fact of the reduced VAT to $6 \%$.

It is acknowledged that the increase in revenue and consequently the net income came as a result of not only the significant reduction in VAT from 20 to $6 \%$, but also as the increased number of tourists and the awareness raising efforts by the GDT in cooperation with business associations to reduce informality. Thus, the officially declared turnover is higher and in this statement it is estimated that the VAT reduction has been determinant.

Table 5: VAT that was paid by the 4,499 taxpayers of the tourism plan registered for

\begin{tabular}{|c|c|c|c|c|c|c|c|}
\hline Period & 2015 & 2016 & $\begin{array}{c}\text { Dif } \\
2016 / 2015\end{array}$ & $\begin{array}{c}\text { Dif \% } \\
2016 / 2015\end{array}$ & 2017 & $\begin{array}{c}\text { Differences } \\
2017 / 2016\end{array}$ & $\begin{array}{c}\text { Dif \% } \\
2017 / 2016\end{array}$ \\
\hline June & $\begin{array}{c}73,197 \\
, 425 \\
\end{array}$ & $\begin{array}{c}89,338,1 \\
50\end{array}$ & $16,140,725$ & $22 \%$ & $\begin{array}{c}98,420,7 \\
98\end{array}$ & $9,082,648$ & $10 \%$ \\
\hline July & $\begin{array}{c}104,96 \\
7,755 \\
\end{array}$ & $\begin{array}{c}114,919 \\
803\end{array}$ & $9,952,048$ & $9 \%$ & $\begin{array}{c}145,143 \\
405\end{array}$ & $30,223,602$ & $26 \%$ \\
\hline August & $\begin{array}{c}140,75 \\
8,417\end{array}$ & $\begin{array}{c}175,458 \\
379\end{array}$ & $34,699,962$ & $25 \%$ & $\begin{array}{c}155,112 \\
692\end{array}$ & $(20,345,687)$ & $-12 \%$ \\
\hline Total & $\begin{array}{c}318,92 \\
3,597\end{array}$ & $\begin{array}{c}\text { 379,716, } \\
332\end{array}$ & $60,792,735$ & $19 \%$ & $\begin{array}{l}398,676, \\
895\end{array}$ & $18,960,563$ & $5 \%$ \\
\hline
\end{tabular}

It is worth mentioning that the estimated value of the VAT based on the turnover of June-August 2017 period has significantly increased compared to the same period of 2015 and 2016. Almost 1/5 (18\%) of the turnover realized by 1259 accommodation units are calculated with the reduced VAT $6 \%$.

\footnotetext{
${ }^{16}$ From the list of 6,337 taxpayers to the tourism plan, only 4,499 of them are registered in VAT, while the rest are small businesses without VAT.
} 
Table 6: Declared VAT for the turnover realized by 1259 accommodation units

\begin{tabular}{|c|c|}
\hline Declared VAT & ALL \\
\hline Calculated VAT for June-August period 2015 & $2,243,826,804$ \\
\hline Calculated VAT for June-August period 2016 & $2,518,044,178$ \\
\hline Calculated VAT for June-August period 2017 & $3,008,691,840$ \\
\hline Calculated VAT with 6\% on June- August 2017 & $203,292,522$ \\
\hline
\end{tabular}

As it can be noticed in the above table the calculated VAT for JuneAugust period is $34 \%$ higher than the same period in 2015 and $19.5 \%$ higher than the same period in 2016. This increase was realized in terms of the negative effect that gives the application rate of $6 \%$ of VAT. The difference on the calculated VAT for the accommodation units on the new regime is 474 million ALL. This figure is associated with all taxpayers who have benefited from the reduction in the VAT rate The same upward trend is also observed in the value of VAT paid by the 1259 taxpayers who exercise activity as accommodation units, which benefit from the application of the reduced VAT rate.

Table 7: VAT paid by the 1259 taxpayers who exercise activity as accommodation units

\begin{tabular}{|c|c|c|}
\hline Period & Description & ALL \\
\hline June -August 2015 & VAT (20\%) & $375,904,459$ \\
\hline June -August 2016 & VAT (20\%) & $495,148,246$ \\
\hline June -August 2017 & VAT $(20 \%$ and 6\%) & $536,226,846$ \\
\hline
\end{tabular}

The VAT paid for the months of June-August 2017 period is about $43 \%$ higher than in the same period of 2015 and about 8.2\% higher than in 2016. This increase was realized in terms of the negative effect that gives the application rate of $6 \%$ of VAT.

\subsection{Employment}

Even in this case there is lack of empiric data. VAT reduction on Tourism sector will enhance investment and also the overall demand by $12 \%$, according to ATA official letter to IMF. This increase in demand will affect employment on three levels:

a) Direct employment (the first line of travel services)

b) Employment related to supplies, goods and services of tourism (second line)

c) Employment in markets from the development of tourism.

According to WTTC, travel and tourism generated 93,500 jobs directly in 2017 (7.7\% of total employment) and this is forecast to grow by $3.3 \%$ in 
2018 to 96,500 (7.8\% of total employment $)^{17}$. This includes employment by hotels, travel agents, airlines and other passenger transportation services (excluding commuter services). It also includes, for example, the activities of the restaurant and leisure industries directly supported by tourists. The total contribution of Travel \& Tourism to employment (including wider effects from investment, the supply chain and induced income impacts, see page 2) was 291,500 jobs in 2017 ( $24.1 \%$ of total employment). This is forecast to rise by $3.8 \%$ in 2018 to 302,500 jobs ( $24.3 \%$ of total employment).

Regarding the performance of the number of employees declared by the 1,259 subjects that exercise the "Accommodation Services" activity and who are directly beneficiaries of the reduced VAT rate of $6 \%$, there is an increase of the number of 5,614 employees declared more from June to August 2017 compared with the same period of 2016.

\begin{tabular}{|c|c|c|c|c|c|c|c|c|c|c|c|}
\hline \multicolumn{2}{|c|}{ June } & Dif & \multicolumn{2}{c|}{ July } & Dif +/- & \multicolumn{2}{c|}{ August } & Dif +/- & \multicolumn{2}{c|}{ Quarter } & Dif +/- \\
& $\mathbf{2 0 1 7}$ & $+/-$ & $\mathbf{2 0 1 6}$ & $\mathbf{2 0 1 7}$ & & $\mathbf{2 0 1 6}$ & $\mathbf{2 0 1 7}$ & & $\mathbf{2 0 1 6}$ & $\mathbf{2 0 1 7}$ & \\
\hline 11,391 & 12,354 & 963 & 13,187 & 15,640 & $\mathbf{2 , 4 5 3}$ & 13,317 & 15,515 & $\mathbf{2 , 1 9 8}$ & 37,895 & 43,509 & $\mathbf{5 , 6 1 4}$ \\
\hline
\end{tabular}

As a result of a sharper situation of tourism companies as well as the joint commitment of government and associations to narrow the businesses to the least penalties, it is noticed a slight increase in the number of employees in this sector ${ }^{18}$.

\subsection{The impact on prices}

Due to lack of data this assessment analysis will not be able to measure the distributional effect empirically, therefore we are going to explain it theoretically. The reduced VAT rate of $6 \%$, theoretically, is supposed to benefit final consumers, as VAT in principle is paid by the consumers. Elasticity measures percentage change in tourism demand as a result of percentage change in price or income (Blake and Jimenez 1997) ${ }^{19}$. A large number of empirical studies have attempted to estimate the price elasticity of demand for international tourism and the results vary. Tourism demand varies significantly as it depends on tourists' origin, destination and purpose of the travel so it can be both inelastic and elastic (Mak 2004) ${ }^{20}$. Based on theoretical basis for the elasticity and the rational behavior of sellers/businesses as utility maximizers, there is a very low likelihood that businesses will react to these changes accordingly.

\footnotetext{
${ }^{17}$ World Travel and Tourisem Council:https://www.wttc.org/-/media/files/reports/economicimpact-research/countries-2018/albania2018.pdf

${ }^{19}$ Blake, A. \& Jimenez, I. "Drivers of Tourism Demand." Annals of Tourism Research. 1997.

${ }^{20}$ Mak, J. "Tourism and the Economy: Understanding the Economics of Tourism." University oh Hawaii Press, 2004.
} 
But unlike as described above, the VAT reduction for the tourism sector did not bring cheaper prices for citizens ${ }^{21}$. This is stated by the Institute of Statistics (INSTAT), where according to them, despite the 3-time tax cut, hotel accommodation prices remained unchanged during the quarter (June, July, August, 2017). According to hospitality representatives, prices remained unchanged because bookings were made before the 6\% VAT application began in June and that the effects of VAT cuts for citizens will be felt in $2018^{\mathbf{2 2}}$.

\section{Conclusion}

The reduction of the VAT rate from $20 \%$ to $6 \%$ in Tourisem Sector in Albania, in hotels and other tourism accommodation facilities have and will bring from Jun 2017 this advantages:.

- Will create a favourable environment for attracting FDI. Will attracts public, private, domestic and foreign investment in the tourism sectors of the economy, identified as strategic sectors that represent high development potential.

- The increasing of the contribution of Tourisem Sector to GDP of our country. The contribution of Tourisem in GDP in 2017 was $8.5 \%$ of GDP. This is forecast to rise by $3.9 \%$ in 2018 . The total contribution of Travel \& Tourism to GDP (including wider effects from investment, the supply chain and induced income impacts) in 2017 was $26.2 \%$ of GDP and is expected to grow by $4.4 \%$ to with $26.3 \%$ of GDP in 2018 .

- The increasing of the revenues from foreign citizens' and the increasing of the net income from tourist operators.

- The VAT cutting in the tourism sector will lead to formalization of the economy and especially to the tourism sector.

- It is noticed a slight increase in the number of employees in this sector.

- The VAT reduction for the tourism sector did not bring cheaper prices for citizens. According to hospitality representatives, prices remained unchanged because bookings were made before the 6\% VAT application began in June and that the effects of VAT cuts for citizens will be felt in 2018. In the future this VAT reduction will bring cheaper prices.

From our data analysis,we saw this positive Impact and effects off VAT reduction in the Tourism Sector and in the Economy of Albania. We fully recommand the VAT reduction .

\section{References:}

${ }^{21}$ Declaration from INSTAT at Top Channel Tv:htpp://top-channel.tv/2017/08/14/instat-ulettvsh-ja-por-fitojne-hotelet/

22 Article from "Dita” Journal:htpp://www.gazetadita.al/ulja-e-tvsh-se-turizmit-asnje-efektne-cmime-per-qytetaret/ 
1. Ministry of Finance: Fiscal indicators regarding consolidated budget of 2017 http://www.financa.gov.al/al/thesari/treguesit-fiskal-sipasbuxhetit-te-konsoliduar

2. Official letter sent to the International Monetary Fund (IMF) in November 2014

3. Word Economic Forum Travel and Tourisem competitiveness Index : http://reports.weforum.org/travel-and-tourism-competitiveness-report2017/country-profiles/\#economy=ALB

4. Draft Law "On an amendment of the Law No. 92/2014 "On value added tax", as amended", published on 5 April 2017 at www.parlament.al

5. Declaration on Top Chanel Tv of Ministre of Finance Mr. Ahmetaj,Date $27.10 \quad$ 2017:http://top-channel.tv/2017/10/27/prbuxheti-2018-ahmetajprioritet-turizmit-lufte-informalitetit/

6. Ligj nr. 107/2017, datë 30/11/2017. Botuar në Fletoren Zyrtare nr. 222, datë 19.12.2017),

7. Ligj nr. 71/2017, datë 27/04/2017. Botuar në Fletoren Zyrtare nr. 113, datë 22 maj 2017.

8. AIDA, Albanian Investment Development Agency: http://aida.gov.al/images/publikime/docs/Albania_Calls_01_low.pdf

9. World Economic Forum: Global Competitiveness Report 2016-2017, Albania, Most problematic factors for doing business, http://reports.weforum.org/global-competitiveness-index/countryprofiles/\#economy=ALB

10. Corruption Perception Index of Transparency International: https://www.transparency.org/country/ALB

11. World Travel and Tourisem Council: https://www.wttc.org//media/files/reports/economic-impact-research/countries2018/albania2018.pdf

12. Generale Directorate of Tax of Albania: Data provided by the GDT. https://www.tatime.gov.al

13. Scan Tv,Economic Tv: https://www.scan-tv.com/tourism-operators-hailvat-reduction-from-20-to-6/

14. Declaration from Prime Minister's office: https://kryeministria.al/en/newsroom/news/tourist-albania-and-itsendless-possibilities-for-exploration\&page $=21$

15. Generale Directorate of Tax of Albania: Data provided by the GDT. https://www.tatime.gov.al

16. From the list of 6,337 taxpayers to the tourism plan, only 4,499 of them are registered in VAT, while the rest are small businesses without VAT.

17. World Travel and Tourisem Council:https://www.wttc.org//media/files/reports/economic-impact-research/countries2018/albania2018.pdf 
18. Blake, A. \& Jimenez, I. "Drivers of Tourism Demand." Annals of Tourism Research. 1997.

19. Mak, J. "Tourism and the Economy: Understanding the Economics of Tourism." University oh Hawaii Press, 2004.

20. Declaration from INSTAT at Top Channel Tv: http://topchannel.tv/2017/08/14/instat-ulet-tvsh-ja-por-fitojne-hotelet/

21. Article from "Dita" Journal: http://www.gazetadita.al/ulja-e-tvsh-seturizmit-asnje-efekt-ne-cmime-per-qytetaret/ 